\title{
THE EFFECT OF PEER ASSESSMENT TOWARDS STUDENTS' SPEAKING SKILL AT SEMESTER II OF UNIVERSITY OF MUHAMMADIYAH JAMBI 2018-2019
}

Syilvia Wenny J. ${ }^{1}$, Rahmat Fajar ${ }^{2}$

Economic Development Department, University of Muhammadiyah Jambi ${ }^{1,2}$ syilviawenny@gmail.com

\begin{abstract}
Speaking subject performed at colleges, especially English language courses, is provided to students to actively develop English speaking skills. However, in fact there are still many students who are less taking advantage of the opportunities given. This has an impact on low student speaking skills. The purpose of the study was to investigate the influence of peer assessment of student speech skills in the second semester of Economics Development of STIE Muhammadiyah Jambi The design of this research is aquasi experimental with a posttest-only control group design. The population of the study was the semester II student of Economics Development of STIE Muhammadiyah Jambi year 2018/2019. The population consisted of 75 students. This research sample was class A as the experimental class and B as the control class. Both classes was taken the value of the speaking test which then be compared. The results of this study showed that students taught using peer assessment had better speaking skills than students taught using the teacher assessment.
\end{abstract}

Keywords: peer assessment; learning motivation; speaking skill

\section{INTRODUCTION}

In English language learning for universities, the ability students to speak using English should be better than the previous level of education. This is due to the time spent that students already have in learning English and insight into the knowledge already gained. With the skills and insight that has been gained will impact the increasingly increasing motivation of students, especially in expressing ideas into the ability to speak. In this phase, the lecturer's task is to facilitate students with learning techniques focused on improving student's speaking skills, supporting learning media and providing feedback for students, so that the ability to Students improved.

But the expectations that were previously presented are still a problem for students. As found in students of Economic Development Department, University of Muhammadiyah Jambi after preliminary research in class, it was found that the ability to speak English is still low. The preliminary research results in the form of $71.22 \%$ of students from 120 students got $45-55$ points, $19.42 \%$ of students got less than 45 points, $6.47 \%$ of students got $56-65$ points and only $2.88 \%$ of students got $66-80$ points.

From those percentages, some causes are found. Firstly, the student-owned English vocabulary was still very limited. It was provenby the repetition of use of the same words in speech. It happened since students less interested in enriching vocabulary. They did not use the vocabulary introduced in speech. Then, students did not use the correct language rules in speaking. Then, students still had difficulties in developing ideas to speak. And they still got difficult in saying words in English. 
To minimize the problems found above, the peer assessment was expected to be a strategy used in the teaching and learning process. By using a peer assessment, students were given the opportunity to give their friends a vote, and inserted them into a material improvement in the ability to speak. In addition, the Peer assessment could also motivate students to improve their English proficiency. In addition, it could also build cooperation in the learning process.

\section{Speaking Skill}

Speaking is a process done to convey ideas into verbal and non-verbal word symbols. These symbols are the ones that are able to make the opponent speak to understand what is delivered. Chameron (2001) reveals that speaking is the use of language to express meaning so that others are able to understand it. Fulcher (2003) also adds that speaking was used to create listeners with the wording of the listener, so that it was meaningful to the listeners. It can be concluded that speaking is a way of sending a mind, expressing meaning and communicating with others using multiple symbols in many contexts. However, speaking is not an easy ability. It requires a lot of experience and practice especially when using foreign languages. Luoma (2004) argues that speaking in foreign languages is difficult and needs a long time to learn. Speakers should have many inputs from other abilities such as listening, writing and reading so that the content is created a good conversation. Thornbury (2005) also mentions that speaking is complex because it contains some skills and knowledge such as features of language and independent knowledge (extra-linguistic ability). All these abilities are put together so that the speaker can create new thoughts.

In speaking skill, there are two supporting skills that can be used by the speaker. It consists of micro and macro skills offered by Brown and Abeywickrama (2010). The micro skills consist of "phonemes and allophones, chunks of language, stress patterns, forms of words and phrases, lexical units or words, fluent speech at different rates of delivery, strategic devices, grammatical word, speech in natural constituents, particular meaning in different grammatical forms, and cohesive devices in spoken discourse".And the macro skills are "completed the components of speaking skill. It consists ofcommunicative functions, sociolinguistics features, links and connections between events and communicate, nonverbal cues along with verbal language, speaking strategies".

In short, in communication, people have to deliver their ideas by having speaking. They speak because they have reason in it. They may speak in some types like imitative, intensive, responsive interactive and extensive. But in doing speaking, speakers need to have some experiences, practices, knowledge, and sub skills; micro and macro skills so that they can speak better for the next chance, especially for the second language learners.

\section{Speaking Assessment}

Brown (2001) mentions there are five components of the ability to speak grammar, vocabulary, comprehension, fluency, pronunciation, and grammar, vocabulary, comprehension, flux and pronunciation and dialogue content. This theory will be used in assessing the student's speaking skills in this study, as several sections have been studied as they study in the classroom. Brown's theory was modified in this 
casse, the "Dialogue content" component is removed, because in this training students will be asked to present themselves (monologues).

\section{Peer Assessment}

Peer Assessment is a strategy that includes peers to assess our capabilities. According to McKay (2006), peer Assessmet is a strategy that can be used as supporting class assessments. Noonan and Duncan (2005) added that the peer assessment is a strategy that engages students in appraisal the peers that bias is assumed to be a form of cooperation in the learning activities. When peer make mistakes, other friends give judgment and criticism so that the same mistakes can be minimised in the future.

\section{Benefits of Peer Assessment}

There are some benefits of peer assessment. Harmer (2007: 150) states that "peer assessment encourages students to monitor each other and as a result helps them to become better at self monitoring". Bryan and Clegg (2006: 106) add that peer assessment confers on students an active role in the feedback process. Students' assessing will make their peer become more efficient in monitoring their progress in improving their skill.

According to Black, et.al (2003: 50) "peer assessment is considered 'uniquely valuable' because it motivates students to be more careful in the work they do, it amplifies the student voice in the learning process, and their learning is improved". It is caused by peer assessment that "it can help each other to make sense of the gaps in their learning and understanding and to get a more sophisticated grasp of the learning process" (Spiller, 2012: 11). Those explanations support Brown and Abeywickrama (2010: 145) who state that "peer assessment is simply one arm of a plethora of tasks and procedures within the domain of learner-centered and collaborative education".

To conclude, peer assessment is involving students in assessing their peers. It affects to them directly. They will feel confident because they have a belief in assessing their peers. Besides, their motivation also rises up because they will try to avoid the mistake or error in learning. When they have their confident and increase their motivation, it leads them to activate their participation in learning. By having all those benefits, they can achieve the aim of learning.

\section{METHOD}

This research is a quasi-experimental study. Researchers manipulated one independent variable later, observing the influence of dependent variables. Here, researchers investigated the effects of independent variable assessments; Peer assessment of dependent variables i.e. speaking skills. This research design was a control group design only posttest. No pre-test was given to the group (controls and treatment groups) to control the effects of simple testing and interaction between testing and treatment.

The population of research was student of semester II of Economic Development Department, University of Muhammadiyah Jambi academic year 2018/2019. The population consisted of 77 students. This research samples were class A as the experimental class and $\mathrm{B}$ as the control class. 
Researchers collected data from students who spoke after giving treatment; Peer assessment and assessment of teachers. Researchers gave the test a monologous talk to students for both classes. At the end of the meeting, students were asked to speak in front of the class about specific topics they liked for about 3 minutes. Their talks were also recorded to facilitate their assessment based on the speaking skills indicator in the score rubric adapted by Brown. There are five components, grammar, vocabulary, pronunciation, smoothness and content. Each indicator has the highest score of 5 and the lowest score is 1 .

\section{FINDINGS AND DISCUSSION}

There were 77 students of semester 2 from the students Economic Development Department, University of Muhammadiyah Jambi year 2018/2019. They spread into 2 classes. And in this study, both classes were taken as samples; The A class consisted of 36 students as an experimental class and class B consisted of 41 students as a control class. The Peer Assessment was treated to experimental classes, while lecturers ' assessments were treated in the control class.

In acquiring the data of students ' speaking skills, posttest was used. As mentioned earlier that both classes had different treatment. Experimental classes applied peer assessments and control classes to apply lecturer assessments. A summary of the data from both classes is shown in the table below:

Table 1.Experimental Classroom Speaking score summary

\begin{tabular}{lccccc}
\hline \multicolumn{1}{c}{ Class } & N & Mean & SD & Max & Min \\
\hline Eksperiment & 36 & 77.39 & 8.36 & 90 & 60 \\
Kontrol & 41 & 71.07 & 7.59 & 84 & 60 \\
\hline
\end{tabular}

In getting scores, rubric scores of speakingwere multiplied by four to get 100. It can be seen from the table above, there were 36 students. The highest score was 90, while the lowest score was 60. The average score of that data is 77.39. In the control class, there were 41 students. The highest score was 84 and the lowest score was 60 . The average score of that data was 71.07.

Before getting the end result of the data, a test of normality was performed for data-ability speech results to ensure that the data was normally distributed. The results of the normality test can be seen from the following table:

Table 2.Summary test normality of speaking ability

\begin{tabular}{llllll}
\hline Variabel & Class & $\mathrm{N}$ & $\mathrm{L}_{\text {observed }}$ & $\mathrm{L}_{\text {table }}$ & Note \\
\hline
\end{tabular}




\begin{tabular}{lccccc}
\hline $\begin{array}{l}\text { Speaking } \\
\text { SKill }\end{array}$ & Experiment & 36 & 0.11336 & 0.1454 & $L_{0}<L_{t}$ \\
& & & & Normal \\
& Control & 41 & 0.1356 & 0.1373 & $L_{0}<L_{t}$ \\
& & & & Normal \\
\hline
\end{tabular}

Then to test the hypothesis used test T. Results of the speech ability of both classes can be seen from the following table:

Table 3.Summary T-Test of speaking ability for experimental and control classes

\begin{tabular}{cccc}
\hline Assessment & $\mathbf{t}_{\text {observed }}$ & $\mathbf{t}_{\text {table }}$ & Note \\
\hline Peer assessment & 3.47 & 1.66 & $t_{\text {observed }}>t_{\text {table }}$ \\
& & & Ha: accepted \\
\hline
\end{tabular}

From the results above, it can be concluded that the value of the observed $\mathrm{T}$ was greater than in the value of the table T. It could be indicated that $\mathrm{Ho} \neg$ rejected and $\mathrm{Ha}$ accepted.

Based on statistical analysis of the hypothesis testing, it was found that the average value of students in the experiment class was higher than that of the students in the control class. It means that students taught using a peer assessment got better results in speaking than those taught using the teacher's judgment. This was in line with the findings of research conducted by Ahangarai, Rassekh and Hamed (2013). They found that the "average peer assessment score was 3.64 which was slightly higher than the 3.42 assessed by the teacher". It happens because the teaching process is focused on students. Topping (1998:250) defines that "peer assessment as a setting in which individuals consider the number, level, value, value, quality of product success or learning outcomes of similar peer status ". Based on this definition, it was clearly defined that the peer assessment allows students to contribute their contributions to their peers who are expected to make their colleague's speaking skills increase. In this study, contributions were given after their companions spoke in front of the class. When delivering, students pay attention to contributions to make it easier to remember them and avoid the same mistakes.

Implementing a peer assessment provides better outcomes for speaking students than those who did not apply a peer assessment. In the teaching process, students were grouped into five students. At each meeting, students were required to present their ideas in front of the class. During the presentation, another group rated their friends. As Harmer (1994:80) suggests that "peer assessment must be conducted during activities so that the students conducting the activity get feedback immediately thereafter". Later, when the group has completed their presentation, they are given questions related to the content as well as contributions that have been noted previously. Note that students getting from their colleagues will be feedback in improving their speaking skills for 
subsequent presentations. This activity makes students examine their associates and provide some input to their peers as well as themselves. It is in line with Harmer (2007:150) stating that "peer assessment encourages students to monitor each other and as a result helps them to become better at self-monitoring". In addition, Brown and Abeywickrama (2010:145) believe that a "peer assessment is just one arm of a large number of tasks and procedures in an educational domain centered on learners and collaboratively. Proven in this study that students become active learners, they give feedback and tell what they know about talking well. The lecturer was only as a facilitator at the time.

On the other hand, students who were taught using teacher assessment did not get better results. They were asked to present their ideas in front of the class, and other friends only paid attention to them. When they were done, their friend commented or questioned related to the content. In the end, the lecturer commented on the student who just did, it could be quality, error occurred, clear strength like what O'Malley and Pierce suggested (1996:43) "that the teacher's comments should be brief and discuss the sample of a particular job. Comments should include strengths and weaknesses in student work ". And it continues to the next presenter. Here, some students do not quite pay attention to the teacher's judgment while some students record feedback from the lecturers. For students who note the lecturer's comments, it does not show them to remember what has been commented on for their presentation, so that the same mistakes occur.

In short, experimental and control classes were given the same material and a good teaching process. They differed from the assessments applied; Peer assessment and assessment of teachers. And it was discovered that students who were taught using the peer assessment got better results in speaking than those taught using the teacher's judgment.

\section{CONCLUSIONS}

Based on the research findings above, it could be concluded that: 1. Students taught using a peer assessment had better speaking skills than students were taught using teacher assessments. The average value of students taught using the peer assessment was 77.39 and students who were taught using the teacher's judgment were 71.07.

This study offered some implications for teaching English especially teaching speaking. It was found that using a peer assessment was more effective than using a lecturer assessment in teaching speech in the 2nd semester of STIE Muhammadiyah Jambi. Teaching speaking by using a peer assessment has a more positive effect to improve speech than using a lecturer's assessment. This assessment leads students to be more active in conveying their ideas.

Based on the findings and conclusions above, some suggestions will be proposed, as follows:

a. It is advisable for English lecturers at STIE Muhammadiyah Jambi to apply the peer assessment as a variation of the speaking teaching strategy. 
$b$. It is recommended for subsequent researchers to develop other research relevant to this research. In addition, they are also advised to do the same research for other skills.

\section{REFERENCES}

Ahangari, Saedeh, Rassekh, \&Hamed. 2013. The Effect of Peer Assessment on Oral Presentation in an EFL Context. International Journal of Applied Linguistics \& English Literature. Vol. 2 No. 3; May 2013.

Black. P., Harrison, C., Lee, C., Marshall, B., \& William, D. 2003. Assessment for Learning: Putting It IntoPractie. Maidenhead: Open University Press.

Bryan, C. \& Clegg, K. 2006. Innovative Assessment in Higher Education. New York: Taylor \& Francis.

Brown, H. D. 2001. Teaching by Principles An Interactive Approach to Language Pedagogy ( $\left.2^{\text {nd }} e d.\right)$. New York: Longman.

Brown, H. D \&Abeywickrama, P. 2010. Language Assessment Principles and Classroom Practices. New York: Longman.

Cameron, L. 2001. Teaching Language to Young Learners. London: Cambridge University Press.

Fulcher, G. 2003. Teaching Second Language. New York: Longman.

Harmer, J. 2007. The Practice of English Language Teaching (4 ${ }^{\text {th }}$ ed.). London: Longman.

Luama, S. 2004. Assessing Speaking. Cambridge: Cambridge University Press.

McKay, Penny. 2006. Assessing Young Language Learners. Cambridge: Cambridge University Press.

Noonan, B \& Duncan, C.R . 2005. Practical Assessment, Research \& Evaluation. Peer and Self Assessment in High Schools. Vol 10 Number 17, November 2005.

Spiller, D. (2012).Assessment Matters: Self Assessment and Peer Assessment, Teaching Development Unit. University of Waikato. Retrieved from http://www.waikato.ac.nz/tdu/pdf/booklets/9_SelfPeerAssessment.pdf

Thornbury, Scott. Toronto: 2005. How to Teach Speaking. New York: Longman.

Topping, K. 1998. Peer-Assessment Between Students In Colleges And Universities. Review of Educational Research. 19(1), 69-75. 